\title{
Effect of Andrographis Paniculata to the Expression of IL-6, IL-17, IL-10, TGF $\beta$, and the Ratio of Treg / Th17 in Sprague Dawley Rats with Atherosclerosis Diet and Cigarette Smoke
}

\author{
Benadette Dian Novita Dewi ${ }^{1}$, Imelda Theodora ${ }^{2}$, Wahyu Dewi Tamayanti ${ }^{3}$, Adi Pramono ${ }^{4}$ \\ ${ }^{1,2,4}$ Medical Faculty Widya Mandala Catholic University \\ ${ }^{3}$ Pharmacy Faculty Widya Mandala Catholic University
}

\begin{abstract}
Atherosclerosis is a chronic, active and progressive inflammatory disease of the arterial wall controlled by native and adaptive immune responses (René, et al 2010). Continuous exposure of oxidized LDL causes macrophages activated more and produces pro-inflammatory cytokines and proteases. The pro-inflammatory cytokines lead to the differentiation of naive $T$ cells tend to become pro-inflammatory effector $T$ cells such as Th1, Th2 and Th17 (T helper) than to counter-inflammatory Tregulator cells. The aim of this study was to determine the role of the ethanol extract of Andrographis paniculata in slowing the inflammatory reaction by increasing the ratio of Treg / Th17 cells and increasing the amount of expression of counter-inflammatory cytokines (IL-10 and TGF $\beta$ ) than proinflammatory cytokines (IL-6 and IL-17) in Sprague Dawley rats with Atherosclerosis Diet and Smoke induction. This study uses a posttest experimental design control study. Samples taken at random. The research was conducted in vivo to demonstrate the effect of ethanol extract of Andrographis paniculata in a variety of dosage on the expression of $I L-6, I L-17, I L-10, T G F-\beta$ and the ratio of Treg / Th17 cells, in Sprague Dawley rats with Atherosclerosis Diet and Smoke induction. The results showed that ethanol extract of Andrographis paniculata at a dose of $1.2 \mathrm{mg} / \mathrm{kg}$ in Sprague Dawley rats with Atherosclerosis Diet and Smoke induction, take effect on $I L-17$, and the ratio of Treg / Th17 cells $(p<0.05)$. Expression of IL-17 was significantly higher in the group of ethanol extract of Andrographis paniculata at a dose of $1.2 \mathrm{mg} / \mathrm{kg}$ compared to the negative control. Based on the above data, it can be concluded that the ethanol extract of Andrographis paniculata can reduce chronic inflammation and the risk of atherosclerosis in the blood vessels of Sprague Dawley rats with Atherosclerosis Diet and Smoke induction
\end{abstract}

Keywords: Andrographis paniculata, atherosclerosis, inflammation, Treg, Th17, IL-10, TGF- $\beta$, IL-6, IL-17

\section{Background}

Atherosclerosis is a chronic inflammatory process in the arterial walls that involve natural and adaptive immune responses. Atherosclerosis is the basic of heart disease and cardiovascular events. Atherosclerosis tends to occur in more than one artery, which gives vascularization to the heart, kidneys and extremities (Lloyd-Jones, et al., 2009). Reported incidence of atherosclerosis occur at the age of 10 -14 years old, the youngest. Prevalence of fatty streaks in the arteries occurred approximately $50 \%$ at the age of 2-15 years old and $85 \%$ at age of 21-39 years old. Fibrous plaque lesion prevalence increased from $8 \%$ at the age of 2-15 years old to $69 \%$ at the age of $26-39$ years old (Hong, 2010). According to the National Health and Nutrition Examination Survey, it is estimated that 17,600,000 Americans over 20 years old suffer from CHD (coronary heart disease) from 2003 to 2006, in USA, the total prevalence in USA for adults aged above 20 years old is $7.9 \%$

Basic Health Research (Riskesdas) Indonesia in 2007 showed the distribution of mortality due to NCDs (noncontagious diseases) increased to 59.5 percent. The largest proportion of causes of death in all age due to NCDs are cardiovascular disease (31.9\%), including stroke (15.4\%), hypertension (6.8\%), ischemic heart disease $(5.1 \%)$ and other heart diseases (4.6\%).
Basically, atherosclerosis is an active inflammatory disease, a chronic and progressive in the arterial wall controlled by natural and adaptive immune responses. The process may eventually result in thrombosis and often fatal as the occurrence of myocardial infarction or ischemic stroke due to rupture of the fibrous cap atheroma (René, et al 2010). This inflammatory process also controls the arterial plaque development and stability (Ait-Oufella, et al., 2011).

This inflammatory process, in the early phase of atherosclerosis occur due to oxidized LDL (Low Density Lipoprotein) exposure on macrophages, and in the late phase, the inflammation is increased because of the exposure to 'hidden molecules' on macrophages. Continuous exposure of a high-fat diet (atherogenic diet) increase the oxidized LDL and the formation of 'hidden molecules' lead to more activated macrophages. Activated macrophages produce proinflammatory cytokines (including IL-1, IL-6 and TNF- $\alpha$ ) and protease enzymes. Pro-inflammatory cytokines result to the differentiation of naive $\mathrm{T}$ cells tend to become proinflammatory effector T cells such as Th1, Th2 and Th17 (T helper) rather than to counter inflammation $T$ regulator cells. As a result of enzyme protease, atherosclerotic lesions became necrotic and rupture, resulting in acute thrombotic, including myocard infarct, stroke and sudden death (Tabas and Kathryn, 2012). The ratio of the Treg / Th17 cells and expression of proinflamatory and counter inflamatory cytokines in atherosclerotic plaques determine the final 


\section{International Journal of Science and Research (IJSR) \\ ISSN (Online): 2319-7064 \\ Index Copernicus Value (2013): 6.14 | Impact Factor (2014): 5.611}

outcome of an atherosclerotic plaque, whether it will rupture or remain stable.

Atherosclerosis management approach based more on an immunological response, inflammation, not much studied. Andrographis paniculata has many clinical benefits, inhibiting HMG Co A reductase. (Patel, et al, 2011), increasing the mRNA (Messenger RNA) and levels of GLUT4 (glucose transporter type 4) (Akbar, 2011), decrease the activity of plasma ACE (angiotensin converting enzyme ) and lipid peroxidation in kidney (Akbar, 2011), increases the acid-soluble sulfhydryl content, cytochrome P450 (CYP450), cytochrome P450 reductase, cytochrome b5 reductase, glutathione S-transferase, and superoxide dismutase, increasing the levels of catalase, glutathione peroxidase, and glutathione reductase (Akbar, 2011), increasing the activity of CAT (catalase), SOD (superoxide dismutase) and GST (Glutathione-S-transferase), inhibits xanthine oxidase and anti-lipid peroxidation (Patidar, et al., 2011), decrease the lipid peroxid and endothelin activity, improve the activity of NO, cGMP (cyclic guanosine monophosphate), and superoxide dismutase (Akbar, 2011). Previous research proved that the fraction of ethyl acetate (EtOAc) of Andrographis paniculata had anti-inflammatory benefits. Later studies isolated the active ingredient using chromatography and found 8 basic ingredients in Andrographis paniculata, that is 5-hydroxy-7,8dimethoxyflavone (1), 5-hydroxy-7,8-dimethoxyflavanone (2), amixof $\beta$-sitosterol (3a ) and stigmasterol (3b), ergosterol peroxide (4), 14-deoxy-14,15dehydroandrographolide (5), and the composition of the new,

19-O-acetyl-14-deoxy-11,12didehydroandrographolide (6a), all the above is the composition of Andrographis paniculata which can significantly inhibit the transcription activity of NF- $\kappa \mathrm{B}$ in RAW 264.7 macrophages, that were stimulated with LPS / IFN- $\gamma(\mathrm{P}<0.05)$. The composition of most of Andrographis paniculata is, 14-deoxy-11,12 didehydroandrographolide (7) and andrographolide (8), both have smaller inhibitory activity but its resistance activity can be enhanced by hydrogenating, oxidating, or acetylisating into its derivative compositions such as hexahydro-14 dehydroxyandrographolide (9) 3.19-dioxolabda-8 (17), 11E, 13-trien-16,15-olide (10)

$.3,19-\mathrm{O}$ diacetylanhydroandrographolide (11) 19-OAcetylanhydroandrographolide (12). All the compositions significantly decrease the levels of TNF-R, IL-6, macrophage inflammatory protein-2 (MIP-2), and nitric oxide (NO) secretion from the RAW264.7 cells that is stimulated with LPS / IFN- $\gamma$, the composition of the 5, 11 and 12 showed the strongest inhibitory effect on NF- $\kappa$ B in cells 264.7, hinted as bioactive ingredient (Wen-Wan ChaoHsiung Kuo Yueh, and .Bi.-Fong Lin, 2010). The study by Wang et al concluded Andrographolide decreased the expression of inflammatory cytokines (TNF alpha, IL-12, IL-1 beta, IL-18 and IL-6) in macrophages induced by LPS, it is consistent with previous reports that andrographolide decrease the mRNA expression of TNF alpha and IL-12 and also decrease production of cytokines in macrophages (Wang, W. et al., 2010).

Hidalgo et al, examined patients with RA (rheumatoid arthritis) and concluded andrographolide (active substance
Andrographolide paniculata) $1.2 \mathrm{mg} / \mathrm{kg}$ orally is effective for reducing symptoms and lowering the serological parameters in patients with rheumatoid arthritis (Hidalgo, et al., 2013).

Andrographis paniculata, until now, has never been studied whether it can slow or stop the inflammatory processes in atherogenesis. Based on the problem and the knowledge that has been described above, it is now studied whether Andrographis paniculata can prevent atherogenesis by analyzing changes in the expression of IL-6, IL-17, IL-10 and TGF- $\beta$ and the ratio of Treg / Th17 cells.

The purpose of this study was to determine the effect of Andrographis paniculata on the expression of IL-6, IL-17, IL-10, TGF- $\beta$ and the ratio of Treg / Th17 cells in Sprague Dawley rats with atherosclerotic diet and cigarette smoke induction.

\section{Research Methods}

Type / Design: This study used experimental design post test control study. 25 Sprague Dawley rats were taken at random. The research was conducted in vivo to demonstrate the effect of ethanol extract of Andrographis paniculata in a variety of dosage on the expression of IL-6, IL-17, IL-10, TGF- $\beta$ and the ratio of Treg / Th17 cells, in Sprague Dawley rats with atherosclerotic diet and cigarette smoke induction.

\section{Tools and Materials}

Tool :

a) Tregulator and Th17 cells examination required equipment fluocytometry: BD FACSCalibur Flow Cytometry System

b) Quantitative Examination of expression of IL-10, TGF- $\beta$, IL-17 and IL-6 using a light microscope with soft ware ImmunoRatio

\section{Material}

\section{Extraction of Andrographis paniculata}

The plant material used in this study is thesambiloto plant (Andrographis paniculata) that was collected and determined at the East Java Provincial Health Office UPT Materia Medica Batu, East Java. The administered dose is $1.2 \mathrm{mg} /$ $\mathrm{kg}$ body weight in accordance with Hidalgo, et al research, using andrographolide for Rheumatoid Arthritis treatment (Hidalgo, et al., 2013; Bertoglio, et al, 2009).

Ethanolic extract preparation can be obtained as follow: 10 grams dry powder of Andrographis paniculata to be extracted with $250 \mathrm{ml}$ of $95 \%$ ethanol by stirriring overnight at room temperature. Then the mixture is stirred in a centrifuge at a speed of $1350 \mathrm{~g}$ at $4^{0} \mathrm{C}$ for 10 minutes. The supernatant extraction then concentrated using a rotary evaporator at $55^{\circ} \mathrm{C}$ in vacuum conditionand then freeze dried. Theformed Dry powder are stored in minus $20^{\circ} \mathrm{C}$ temperature. The content of andrographolide in the extract was determined by LC / MS. The ethanolic extract contain $53 \mathrm{mg}$ of andrographolide and $30 \mathrm{mg}$ of 14-deoxy-11,12didehydroandrographolide per gram of extract (Chen, et al., 2013).

\section{Volume 5 Issue 2, February 2016}




\section{International Journal of Science and Research (IJSR) \\ ISSN (Online): 2319-7064 \\ Index Copernicus Value (2013): 6.14 | Impact Factor (2014): 5.611}

Andrographolide purification $1 \mathrm{mg} / \mathrm{kg}$ body weight or the administration of the ethanol extract of the stems and the leaves via intra gastric for $25 \mathrm{mg} / \mathrm{kg}$ body weight in mice can induce the formation of antibodies and delayed type response against sheep red blood cells (Jayakumar, et al., 2013)

\section{Atherogenic Diet}

Normal diet is made according to the recommendations of the American Institute of Nutrition (AIN). Rats were given drinking water as needed during the experiment. The composition of a normal diet is 66\% Comfeed PAR-s, 33\% of wheat powder, and water.

Rat model of atherosclerosis was made by administering 1) a high-fat diet for 90 days, so it can increase the risk of atherosclerosis. Atherogenic diet was made by mixing Comfeed PAR-S 50\%, wheat flour 25\%, 0.125\% cholic acid, lard $8.05 \%$, goats oil $10 \%$, coconut oil $1 \%$ and egg yolk $5 \%$ (Hrapkiewicz et al, 2007; Sacher et al, 2000) (Nur Permatasari, Dian Nugrahenny, Husnul Khotimah, F., 2012. Animal Disease Model) and PTU (propylthiouracil) 0.2\%. (Zhou Bi-rong, P. et al (2011), DhirgoAdj. (2007), and 2) cigarette smoke for 60 days. Buffer solution

\section{Preparation of Mice}

25 Sprague Dawley rats were obtained from the Inter University Centre (PAU) Gajah Mada University, healthy, weight $200 \pm 25$ g, aged 4-8 weeks, kept in individual cages with open ventilation, room temperature $21-23^{\circ} \mathrm{C}$ and humidity of $55 \pm 5 \%$, and the illumination of 12 -hour light (at 7:00 a.m. to 7:00 p.m.) 12 hours of darkness (19:00 to 07:00). Before treatment, the mice performed

acclimatization for 1 week and were divided into 5 equal groups (each of 5 mice), which is 1 negative control group, I Positive Control group and 3 treatment groups.

\section{Taking Specimens}

Under ketamine 2mg / 200gram body weightanesthesia, the blood was taken from the heart of the rats, and partially separated into a container containing the heparin anticoagulant. Whole blood with heparin is used for checking the number of cells and Th17 Tregulator fluocytometry method. The rats dissected for aortic arch were taken and fixed for immunohistochemical examination. The Immunohistochemical examination perform to see the IL-6, IL-17, IL-10 and TGF- $\beta$ expressions.

\section{Data Processing and Analysis}

The collected data will be analyzed with SPSS version 22 . The expression of IL-6, IL-17, IL-10, TGF- $\beta$, the Treg / Th17 cells ratio between the treatment groups wereexamined for the homogeneity and the Shapiro-Wilk normality. If the data is homogen and normally distributed, then be proceed with the difference analysis between the significant groups with one-way ANOVA, with a statistical significance of $\mathrm{p}$ $<0.05$.

\section{Approval of Ethics (Ethical Implications Animal)}

This research has gained ethical feasibility of the Ethics Committee of the Faculty of Medicine, Surabaya Widya Mandala Catholic University no. 011134 / WM12 / Q / 2015.

\section{Research Result}

Tabel 1 : Mean Results

\begin{tabular}{|c|c|c|c|c|c|c|}
\hline Variabel & Group 1 & Group 2 & Group 3 & Group 4 & Group 5 & P (ANOVA) \\
\hline BB & $335,40 \pm 39,95$ & $323,80 \pm 24,13$ & $344,40 \pm 37,37$ & $331,00 \pm 12,49$ & $356,00 \pm 16,23$ & 0,444 \\
\hline TREG & $0,76 \pm 0,23 *$ & $0,38 \pm 0,27 *$ & $14,99 \pm 8,50^{*}$ & $1,41 \pm 0,75^{*}$ & $0,71 \pm 0,12^{*}$ & 0,000 \\
\hline TH17 & $4,796 \pm 0,74$ & $6,294 \pm 4,76$ & $9,736 \pm 6,85$ & $6,74 \pm 1,31$ & $11,96 \pm 5,41$ & 0,124 \\
\hline TREG/TH17 RATIO & $0,156 \pm 0,293$ & $0,0618 \pm 0,009$ & $1,698 \pm 0,635^{*}$ & $0,219 \pm 0,129$ & $0,0656 \pm 0,0185$ & 0,000 \\
\hline TGF & $9,160 \pm 10,98$ & $40,674 \pm 21,31$ & $35,672 \pm 21,99$ & $35,798 \pm 37,22$ & $19,562 \pm 8,26$ & 0,177 \\
\hline IL-10 & $11,50 \pm 18,75$ & $13,55 \pm 7,07$ & $6,85 \pm 2,03$ & $2,814 \pm 2,20$ & $4,99 \pm 4,41$ & 0,354 \\
\hline IL-17 & $8,714 \pm 7,20^{*}$ & $36,098 \pm 19,38$ & $58,38 \pm 25,92^{*}$ & $30,748 \pm 23,97$ & $73,988 \pm 27,22^{*}$ & 0,001 \\
\hline IL-6 & $19,232 \pm 26,08$ & $37,734 \pm 25,35$ & $35,648 \pm 28,64$ & $31,146 \pm 25,07$ & $48,44 \pm 28,98$ & 0,552 \\
\hline
\end{tabular}

Note: * there is a difference between groups in a post hoc analysis to determine the effect of treatment on the results between the treatment group and the control group.

In Table 1 it is known that Spraque Dawley rat body weight did not differ between each group. The mean differences between significant groups shown in Treg result, Treg / Th17 ratio and IL-10 ( $<0.05)$.

IL-17 expression by IHC using ImmunoRatio 
International Journal of Science and Research (IJSR)

ISSN (Online): 2319-7064

Index Copernicus Value (2013): 6.14 | Impact Factor (2014): 5.611

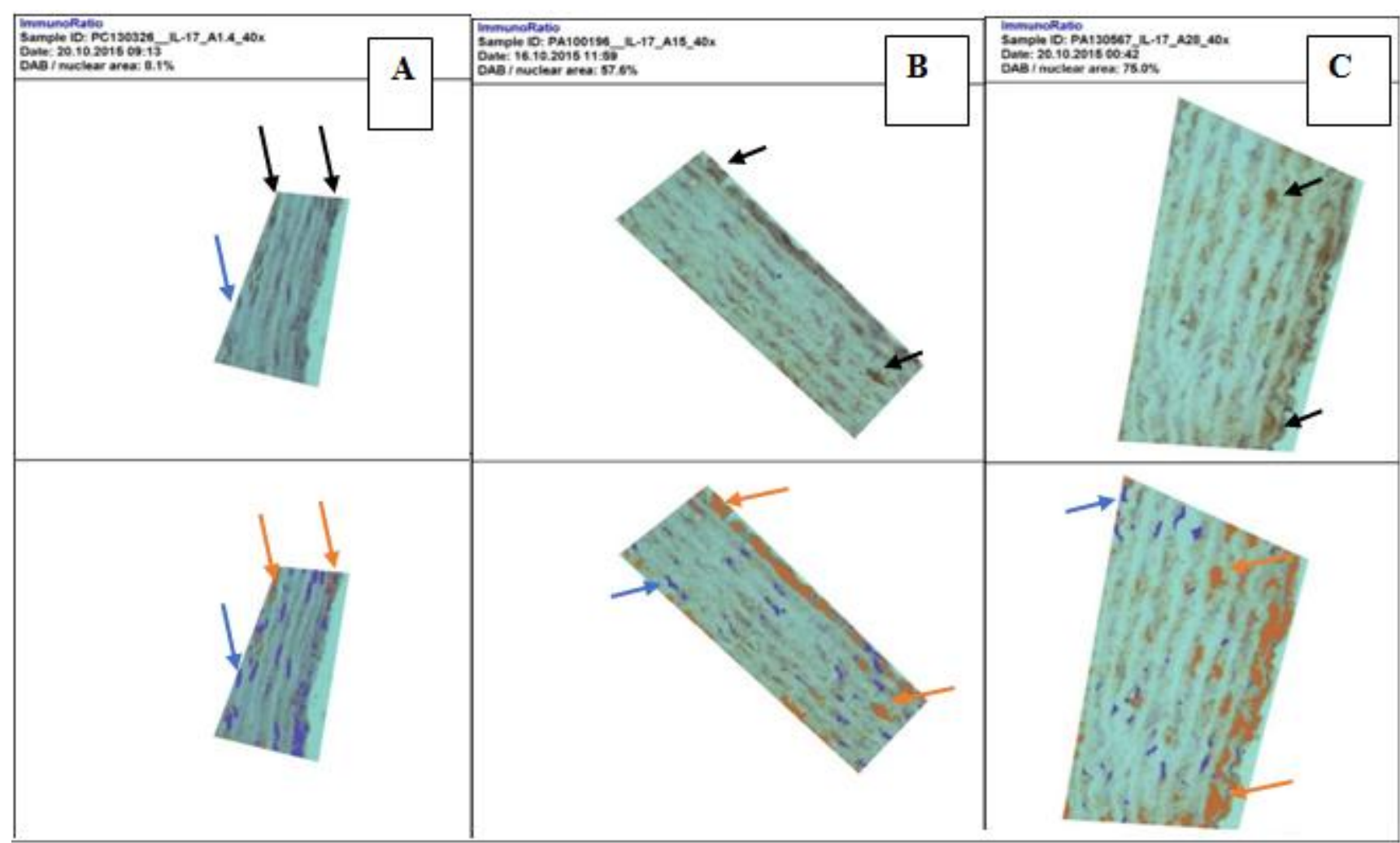

Figure 1 The expression of IL-17 in the aortic arch group 1 (a), 3 (b), 5 (c). Black arrow is expression of IL-17 were stained with immunohistochemistry DAB, medium brown arrows is expression of IL-17 were detected by the software ImmunoRatio, the blue arrow is the nucleus of cells that do not express IL-17. Group 1 was significantly different with group 3 and 5 indicate the occurrence of chronic autoinflamasi process in groups 3 and 5

\section{Discussion of Results}

Interleukin-17 (IL-17) is a pleiotropic cytokine with proinflammatory functions, mainly plays a role in the progression of inflammatory diseases and tissue transplant rejection reactions in humans (Afzali, et al, 2007). IL-17 is a cytokine that is produced largely by leukocytes and pathologically plays role in autoimmune diseases through regulation of the expression of chemokines and leukocyte migration to inflammatory sites. (Butcher \& Galkina, 2011). Expression of IL-17 were higher in the arterial wall with plaques than without plaque. (Gao et al, 2010). IL-17 is the major effector molecule of Th17 cells (Gao et al, 2010).

This study took samples from the aortic arch, a predilection for the occurrence of atherosclerotic plaques because the strongest inflammatory reaction occurred around the aortic arch due to turbulent blood flow. The significantly high expression of IL-17 in group 5 than in group 1 indicates that auto inflammatory reaction has been and is happening in group 5,indicate that the treatment given was to the point where the autoinflammation happen. This reaction is not just the usual acute inflammation, as IL-17 is actually a cytokine markers of chronic inflammation and autoinflammation.

Autoinflamation itself, in the process of atherosclerosis, are the result of a lot of apoptotic cells, that is endothelial cells, smooth muscle cells and macrophages which failto be cleared by healthy macrophages. This clearance failurehave consequences in the exposure of the 'hidden molecules' which is not recognized by the surrounding macrophages. Continuous exposure of oxidized LDL and 'hidden molecules' cause the more activated macrophages and produce pro-inflammatory cytokines including IL-1, IL-6, IL-17 and tumor-necrosis factor (TNF- $\alpha$ ) and protease enzymes. These pro-inflammatory cytokines lead to the differentiation of naive $\mathrm{T}$ cells tend to become effector $\mathrm{T}$ cells such as pro-inflammatory Th1, Th2 and Th17 ( $\mathrm{T}$ helper) rather than into cells Tregulator counter inflammation. (Tabas and Kathryn, 2012).

'Hidden molecules' actually are molecules that exist in macrophages such as heat shock proteins (HSP), HighMobility Group Box 1 (HMGB1), monosodium urate (MSU) and others. 'Hidden molecules' out of the cells because the cells were apoptotic but not immediately phagocytes (clearance) by macrophages and subsequently become necrotic. The three major cell types in atherosclerotic processes that involved in apoptosis are macrophages, SMC and endothelial cells. Apoptotic cells are formed from the accumulation of free cholesterol in macrophages and high oxidized LDL extra cells, production of proinflammatory cytokines such as TNF- $\alpha$ and release of ROS in large quantities by macrophages, growth factor withdrawal, hypoxia and cells interactions (eg binding of Fas-ligand to Fas) (Schrijvers, et al., 2007).

Levels of IL-17 group 3 shows a significant difference with group 1,indicates there are already and is in the process autoinflamation in group 3. The levels of IL-17 3 groups showed no significant difference compared with group 5, indicating similarity inflammatory response in this case the levels of IL -17 in group 3 as well as in group 5. This is because the inflammatory response is always balancedby the 


\section{International Journal of Science and Research (IJSR) \\ ISSN (Online): 2319-7064 \\ Index Copernicus Value (2013): 6.14 | Impact Factor (2014): 5.611}

counter inflammation during immune response of the body to function properly. The ability to be balance in group 5 seem to decreased so that IL-17 is overexpression, while in group 3 the balancingcapabilities of the inflammatory response are still functioning properly. It is observable from the systemic Treg levels and the Treg / Th17 ratio that significantly different between the group 3 compared with any other group. It is possible that the positive effect in reducing the inflammation ofAndrographolide paniculata, that we found in this project, was referred to the increasing number of Treg cells than supress the production of IL-17.

Treg cell in group 3 significantly very prominent higher than in group 2, 4 and 5 indicate an increase in T cell polarization towards Treg. Highly possible in the group 3 the eferositosis optimal occurs, this is related to the Andrographolide paniculata dose given to the group thatis the same as given by Hidalgo et al in a study ofrheumatoid arthritis (RA)patients.Hidalgo concluded $1.2 \mathrm{mg} / \mathrm{kg}$ body weight andrographolide (active substance of Andrographolide paniculata) orally is effective for reducing symptoms and lowering the serological parameters in rheumatoid arthritis patients. (Hidalgo, et al., 2013).

The clearance of apoptotic cells is called eferositosis, an effort that is fast and efficient of macrophages to clear apoptotic cells (apoptotic cell clearance), so as not to become necrotic and post-apoptotic inflammation(Liao, et al., 2012). Eferositosis or the clearance of apoptotic cells, has a benefit in inhibiting the production of proinflammatory cytokines by macrophages, such as IL- $1 \beta$, IL- 8 and TNF- $\alpha$ through the mechanism of suppression which involves the secretion by autocrine and paracrine of cytokine Transforming Growth Factor $\beta$ (TGF- $\beta$ ). TGF- $\beta$ is then used to lower the monocyte recruitment process.

Eferositosis also useful in inhibiting the expression of proinflammatory cytokines family of IL-12 (IL-12, IL-23, IL27 ), and stimulates the production of cytokines counterinflammatory IL-10 so the surrounding tissue protected from excessive inflammatory responses of apoptotic cells content that were immunogenic (Schrijvers, et al., 2007).

Eferositosis also affects the inhibition of the expression of iNOS (inducible nitric oxide synthase) and the stimulation of the expression of arginase- 1 in the macrophage cell line RAW 264, thereby prevent the formation of reactive and damaging NO. Besides this clearance process have an impact in the production of angiogenic growth factor (Ariel, and Serhan, 2012).

Effective eferositosisproduce at least three important protective effect, that this process cleans the cells before membrane damage ended in leakage intracellular toxic ingredients, in addition, this process triggers of IL-10 and TGF- $\beta$ anti-inflammatory response and this processes encourages macrophages resistance to eferositosis further, so not to die because of ingestion toxic material factors of apoptotic cells. The resistance effect include, esterification and efflux of cholesterol, oxidized lipid efflux of proapoptotic and cell survival pathway through Akt pathway and Nuclear Factor Kappa B (NFKB) (Moore, and Tabas, 2011).
Efficient and continuously eferositosis apoptotic cellsis a critical point to maintain the anti-inflammatory environment, against the proinflammatory response and prevent the progression of the lesion. (Ait-Oufella, et al., 2007).

Andrographolide paniculata influence in reducing the inflammation associated with the ability of Andrographolide,the active substance in Andrographolide paniculata, that have a strong ability to limit inflammation in RAW 264.7 macrophages (mouse leukaemic monocyte macrophage cell line) that arestimulated with LPS. In this study, Lee et al showed Andrographolide can decrease the expression of SOCS1 and 3 (suppressors of cytokine signaling in macrophages and monocytes) that are stimulated by LPS.Along with decreasing levels of SOCS1 and 3 mRNA, Andrographolide can further restrict the apoptotic signaling macrophages and activates the mitochondrial membrane potential. (Suchy, et al, 2012

Andrographolide is a lactone diterpenoid bicyclic derived from the extract of Andrographis paniculata. The molecular and cellular imunomodulatorcapacity remains unclear, but in this study we demonstrated its ability to lower the adaptive immune response, both humoral and cellular. in vivo, Andrographolide can interfere $\mathrm{T}$ cell proliferation and cytokine release in administration stimulating allogenik material. In observation, exposure andrographolide togetherwith allogenik material can diminishT cells activation by dendritic cells in total. (Iruretagoyena, et al, 2005).

The increased levels of Treg cells is followed by a significantly increasing Treg / Th17 ratio occurred in group 3 than in any other groups. Group 3 achieve a new balance in dealing with the induction that causes chronic inflammation. Treg cells play a role in limiting inflammation by cytolysis and apoptosis, which regulatory $\mathrm{T}$ cells produce and the secrete Granzyme / perforin which working directly devastate effector $\mathrm{T}$ cells. Recent research shows the suppressive effects of regulatory $\mathrm{T}$ cells through inhibition of microRNA-155 CD4 + T helper cells. (Pastrana, et al., 2012). Of course the end result of an inflammation is the result of a dynamic balance between pro-inflammatory and counter inflamatory between Th17 cells and T regulator(Pastrana, et al., 2012).

\section{Conclusion}

1)Provision of ethanol extract of Andrographis paniculata in Sprague Dawley rats induced with atherosclerotic diet and cigarette smoke has an effect on IL-17, and Treg / Th17 cells ratio

2)Expression of IL-17 was significantly higher in the group of ethanol extract of Andrographis paniculata at a dose of $1.2 \mathrm{mg} / \mathrm{kg}$ body weight compared with the negative control

3)Provision of ethanol extract of Andrographis paniculata in Sprague Dawley rats induced with atherosclerotic diet and cigarette smokesignificantly affect the number of Treg cells in the group of ethanol extract of Andrographis paniculata at a dose of $1.2 \mathrm{mg} / \mathrm{kg}$ compared with other groups 


\section{International Journal of Science and Research (IJSR) \\ ISSN (Online): 2319-7064 \\ Index Copernicus Value (2013): 6.14 | Impact Factor (2014): 5.611}

4)The number of Treg cells was highest among ethanol extract of Andrographis paniculata at a dose of $1.2 \mathrm{mg} / \mathrm{kg}$ body weight.

5)Provision of the ethanol extract of Andrographis paniculata in Sprague Dawley rats induced with atherosclerotic diet and cigarette smokeaffect the expression of IL-17 and the number of Treg cells, especially in the group of ethanol extract of Andrographis paniculata at a dose of $1.2 \mathrm{mg} / \mathrm{kg}$ body weight.

Based on the above data, it can be concluded that the ethanol extract of Andrographis paniculata can reduce chronic inflammation and the risk of atherosclerosis in the blood vessels of Sprague Dawley rats induced with atherosclerotic diet and cigarette smoke.

\section{Acknowledgements}

Wewould like to thank to Badan Penelitian dan Pengembangan Kesehatan Kemenkes RI for RisbinIptekdok research fund and facilities support from Dean of the MedicalFaculty Widya Mandala Catholic University Surabaya and Dean of Pharmacy Faculty Widya Mandala Catholic University Surabaya. We also would like to thank to the Chief of Biomedic Laboratory Medical Faculty in Brawijaya University and Pharmacology Laboratory Chief of Medical Faculty in Brawijaya University for the measurementprocess.

\section{References}

[1] Abcam, 2012. IL17 Rat ELISA Kit ( with color giving dyes ). Rat IL17 ELISA Instruction for use, pp.1-40.

[2] Abcam, 2012. TGF- $\beta 1$ Mouse ELISA Kit ( with color giving dyes ). Mouse TGF- $\beta 1$ ELISA, Instruction for Use, pp.1-40.

[3] Abcam, 2013. IL-10 (Interleukin-10) Rat ELISA Kit. Instructions for Use, (September), pp.1-21.

[4] Abcam, 2013. IL-6 (Interleukin- 6) Rat ELISA Kit. Instructions for use, 6(September), pp.1-20.

[5] Ait-Oufella, H. et al., 2011. Recent advances on the role of cytokines in atherosclerosis. Arterioscler Throb Vasc Biol, 31(5), pp.969-79. Available at: http://www.ncbi.nlm.nih.gov/pubmed/21508343 [Accessed March 12, 2012]

[6] Akbar, S., 2011. Andrographis paniculata: A Review of Pharmacological Activities and Clinical E ects. Alternative Medicine Review, 16(1), pp.66-77

[7] Aprahamian, T. et al., 2004. Impaired Clearance of Apoptotic Cells Promotes Synergy between Atherogenesis and Autoimmune Disease The Journal of Experimental Medicine. , 199(8).

[8] Aprahamian, T., 2011. Autoimmunity, Atherosclerosis and Apoptotic Cell Clearance. Inflammation, Chronic Diseases and Cancer - Cell and Molecular Biology, Immunology and Clinical Bases, Boston Uni, pp.75 96. Available at: www.intechopen.com

[9] Ariel, A. \& Serhan, C.N., 2012. New lives given by cell death: macrophage differentiation following their encounter with apoptotic leukocytes during the resolution of inflammation. Frontierin Immunology, 3(January), pp.1-6
[10] Bertoglio, R.A.B, et all, 2009. Efficacy of an Andrographis paniculata composition for the relief of rheumatoid arthritis symptoms: a prospective randomized placebo-controlled trial. Clin Rheumatol.

[11] Bharati, B.D. et al., 2011. Pharmacological Activity of Andrographis Paniculata: A Brief Review Bharati et al . Pharmacologyonline, 10(2), pp.1-10.

[12]Blasi, C., 2008. The autoimmune origin of atherosclerosis. Atherosclerosis, 201, pp.17-32

[13] Boamponsem \& , A.G, B., 2011. The Role of Inflammation in Atherosclerosis. Adv. Appl. Sci. Res, 2(4), pp.194-207

[14] Braun, N.A. \& Major, A.S., 2010. Natural Killer T Cells and Atherosclerosis: Form and Function Meet Pathogenesis. J Innate Immun, pp.316-324.

[15] Chao, W. \& Lin, B., 2012. Hepatoprotective Diterpenoids Isolated from Andrographis paniculata. Chinese Medicine, 3(September), pp.136-143

[16] Chen, H.-W. et al., 2013. Andrographis paniculata Extract and Andrographolide Modulate the Hepatic Drug Metabolism System and Plasma Tolbutamide Concentrations in Rats. Evidence-based complementary and alternative medicine : eCAM, 2013, pp.1-12.

[17] Chen, S., Crother, T.R. \& Arditi, M., 2010. Emerging Role of IL-17 in Atherosclerosis. , 90048, J Innate Immun, ;2: pp 325-333

[18] Dandu, A.M. \& Inamdar, N.M., 2009. Evaluation of beneficial effects of antioxidant properties of aqueous leaf extract of Andrographis paniculata in STZ-induced diabetes. Pakistan journal of pharmaceutical sciences, 22(1), pp.49-52. Available at: http://www.ncbi.nlm.nih.gov/pubmed/19168420

[19] Dey, Y.N. et al., 2013. Phytopharmacological review of Andrographis paniculata ( Burm . f ) Wall . ex Nees. International Journal of Nutrition, Pharmacology, Neurological Diseases, 3(1), pp.3-10

[20]DhirgoAdj. 2007. Imunohistochemtstry Method to Detect C Reactive Protein in Atheroma Plaques of Sprague Dawley Rats Fed High Lipid Ration. J. Sain Vet, 25(I),11-16.

[21]Dziekiewicz, M., Kozlowski, W. \& Maruszynski, M., 2008. Immunology and atherosclerosis: the possible mechanisms. Int. Rev. Allergol. Clin. Immunol, 14(3), pp.59-62.

[22]EBioscience, 2013. Cell Preparation for Flow Cytometry

[23] Finn, A.V. et al., 2010. History of Discovery Concept of Vulnerable / Unstable Plaque. Arterioscler Thromb Vasc Biol, 30, pp.1282-1292

[24]Ford, M.A., Allison, T.G. \& Lerman, A., 2010. New Approaches to the Concept of Primary Prevention of Atherosclerosis Endothelial dysfunction. Current Treatment Options in Cardiovascular Medicine, 10, pp.73-82.

[25] Göran K. Hansson, M.D., P.D., 2005. Inflammation, Atherosclerosis, and Coronary Artery Disease. The new england journal of medicine, pp.1685-1695.

[26] Gotsman, I., Gupta, R. \& Lichtman, A.H., 2007. The Influence of the Regulatory $\mathrm{T}$ Lymphocytes on Atherosclerosis. ArteriosclerosisThrombosis and Vascular Biology, 27, pp.2493-2495.

[27] Groyer, E. et al., 2007. Atheroprotective Effect of CD31 Receptor Globulin Through Enrichment of Circulating 


\section{International Journal of Science and Research (IJSR) ISSN (Online): 2319-7064 \\ Index Copernicus Value (2013): 6.14 | Impact Factor (2014): 5.611}

Regulatory T-Cells. Journal of the American College of Cardiology, 50(4), pp.344-350

[28] Grundtman, C. \& Wick, G., 2011. UKPMC Funders Group The autoimmune concept of atherosclerosis. Curr Opin Lipidol, 22(5), pp.327-334

[29] Grundtman, C. et al., 2011. Heat Shock Protein 60 and Immune Inflammatory Responses in Atherosclerosis. Arterioscler Thromb Vasc Biol, 31, pp.960-968

[30] Gui, T. et al., 2012. Diverse Roles of Macrophages in Atherosclerosis: From Inflammatory Biology to Biomarker Discovery. Mediators of Inflammation, 2012, pp.1-14

[31] Hansson, G.K. \& Libby, P., 2006. The immune response in atherosclerosis: a double-edged sword. , Nature Reviews Immunology 6(July), pp.508-519

[32] Haraba, R. \& Antohe, F., 2011. T Cells Are Active Participants In The Progression Of Atherosclerotic Plaques. Digest Journal of Nanomaterials and Biostructures, 6(4), pp.1529-1534

[33] Hidalgo, M.A. et al., 2013. Andrographolide a New Potential Drug for the Long Term Treatment of Rheumatoid Arthritis Disease. InTech, pp.247-270.

[34]Hong, Y.M., 2010. Atherosclerotic Cardiovascular Disease Beginning in Childhood. Korean Circ J, 40, pp.1-9.

[35] Jayakumar, T. et al., 2013. Experimental and Clinical Pharmacology of Andrographis paniculata and Its Major Bioactive Phytoconstituent Andrographolide. Evidencebased complementary and alternative medicine: eCAM, 2013, pp.1-17

[36] Jie, Z., 2007. Effects of Andrographitis Paniculata Extracts on the Expression of CD40 in Endothelial Cells. Journal of Huazhong University of Science and Technology, 27(2), pp.138-141

[37] Laurano, L. L., 2011, Uji Efek Antiinflamasi Fraksi Etil Asetat Ekstrak Etanol Daun Mindi (Melia azedarach L.) pada Tikus Putih. Skripsi Sarjana, Unika Widya Mandala, Surabaya, 36

[38] Laurano, L. L., 2011, Uji Efek Antiinflamasi Fraksi Etil Asetat Ekstrak Etanol Daun Mindi (Melia azedarach L.) pada Tikus Putih. Skripsi Sarjana, Unika Widya Mandala, Surabaya, 36

[39]Li, M. et al., 2008. Psychological stress increases expression of aortic plaque inter- cellular adhesion molecule-1 and serum inflammatory cytokines in atherosclerotic rabbit model. Journal of Geriatric Cardiology, 5(4), pp.1-8

[40] Liao, X. et al., 2012. Macrophage Autophagy Plays a Protective Role in Advanced Atherosclerosis. Cell Metabolism, 15, pp.1-9. Available at: http://dx.doi.org/10.1016/j.cmet.2012.01.022

[41] Lloyd-jones, D. et al., 2009. Heart Disease and Stroke Statistics — 2010 Update A Report From the American Heart Association. Circulation, 121, pp.410-528.

[42] Mallat, Z. et al., 2009. The role of adaptive $\mathrm{T}$ cell immunity in atherosclerosis. J. Lipid Res, April supp, pp.364-369

[43] Matsuura, E., Kobayashi, K. \& Lopez, L.R., 2008. Preventing autoimmune and infection triggered atherosclerosis for an enduring healthful lifestyle. Autoimmunity Reviews, 7, pp.214-222

[44] Minsky, M., Cremer, C. \& Clsm, T., 1978. Confocal laser scanning microscopy. , pp.1-4.
[45] Moore, K.J. \& Tabas, I., 2011. Macrophages in the pathogenesis of atherosclerosis. Cell, 145(3), pp.341-55

[46] Mor, A. et al., 2006. Altered status of CD4 1 CD25 1 regulatory $\mathrm{T}$ cells in patients with acute coronary syndromes. European Heart Journal, 27, pp.2530-2537

[47] Newby, A.C. et al., 2009. Europe PMC Funders Group Vulnerable atherosclerotic plaque metalloproteinases and foam cell phenotypes. Thromb Haemost, 101(6), pp.1006-1011.

[48] Nilsson, J. \& Hansson, G.K., 2008. Autoimmunity in atherosclerosis: a protective response losing control ? Journal of Internal Medicine, 263, pp.464-478

[49] Niranjan, A., Tewari, S.K. \& Lehri, A., 2010. Biological activities of Kalmegh ( Andrographis paniculata Nees ) and its active principles-A review. Indian Journal of Natural Products and Resources, 1(June), pp.125-135

[50] Oksjoki, R., 2006. Focus on the Role of the Complement System. Wihuri Research Institute Helsinki, Finland and Faculty of Medicine University of Helsinki Helsinki, Finland

[51] Pastrana, J.L. et al., 2012. Regulatory T Cells and Atherosclerosis. J.Clin Exp Cardiology, S12:002, pp.111

[52] Patel, H.D., Shah, G.B. \& Trivedi, V., 2011. Investigation of HMG Co A Reductase Inhibitory Activity of Antihyperlipidemic Herbal Drugs In Vitro Study. Asian J. Exp. Biol. Sci, 2(1), pp.63-68

[53] Patidar, S. et al., 2011. Biochemical Constituents in Kalmegh ( Andrographis paniculata Nees .) Under Various Row Spacing, s and Nitrogen Levels. World Appl Sci J, 15(8), pp.1095-1099

[54] Pharmingen, B., 2011. Technical Data Sheet Mouse Th17 / Treg Phenotyping Kit. BD Pharmingen ${ }^{T M}$, pp.14

[55] Ravichandran, K.S., 2010. Find-me and eat-me signals in apoptotic cell clearance: progress and conundrums. J.Exp. Med, 207(9), pp.1807-1817

[56] Ravichandran, K.S., 2011. Review Beginnings of a Good Apoptotic Meal :Find-me and Eat-Me Signaling Pathways. Immunity, 35(4), pp.445-455. Available at: http://dx.doi.org/10.1016/j.immuni.2011.09.004

[57] René R. S. Packard, M.D. Andrew H. Lichtman, Ph.D., M.D., And Peter Libby, M.D., 2010. NIH Public Access. Innate and Adaptive Immunity in Atherosclerosis, 31(1), pp.1-27.

[58]Rifa'i, M., 2010. Andrographolide Ameliorate Rheumatoid Arthritis by Promoting the Development of Regulatory T Cells. J. Trop. Life. Science, I(1), pp.5-8.

[59] Saengkhae, C. \& Raksapol, K., 2009. Antiproliferation and Apoptosis of Crude Extract of Andrographis paniculata Ness. on Human Breast Adenocarcinoma Cells (MCF-7) In Vitro. Journal of Thai Traditional and Alternative Medicine, 7(2), p.2009

[60] Schiopu, A. \& Barsan, A., 2009. The Use Of Regulatory T Cells For The Treatment Of Atherosclerosis. Journal of Experimental Medical \& Surgical Research, XVI(2), pp.149-155.

[61] Schrijvers, D.M. et al., 2007. Phagocytosis in atherosclerosis: Molecular mechanisms and implications for plaque progression and stability. Cardiovascular Research, 73, pp.470-480 


\section{International Journal of Science and Research (IJSR) \\ ISSN (Online): 2319-7064 \\ Index Copernicus Value (2013): 6.14 | Impact Factor (2014): 5.611}

[62] Scull, C.M. \& Tabas, I., 2011. Mechanisms of ER Stress-Induced Apoptosis in Atherosclerosis. Arterioscler Throb Vasc Biol, 31, pp.2792-2797

[63] Seimon, T. \& Tabas, I., 2009. Mechanisms and consequences of macrophage apoptosis in atherosclerosis. J. Lipid Res., 50, pp.S382-S387

[64] Sheeja, K. \& Kuttan, G., 2010. Andrographis paniculata Downregulates Proinflammatory Cytokine Production and Augments Cell Mediated Immune Response in Metastatic Tumor-Bearing Mice. Asian Pacific $J$ Cancer Prev, 11, pp.723-729

[65] Smith, C., 2012. TUNEL Assay Kits for Apoptosis Detection. Biocompare Editorial Articles, pp.1-4.

[66] Spagnoli, et all., 2007. Role of Inflammation in Atherosclerosis .J Nucl Med, 48(11), pp.1800-1815

[67] Sukardiman, H., 2007. Apoptosis Inducing Effect Of Andrographolide On Td-47 Human Breast Cancer Cell Line. Afr. J. Trad. CAM, 4, pp.345-351

[68] Tabas and Kathryn J Moore, 2012. The Cellular Biology of Macrophages in Atherosclerosis. Cell, 145(3), pp.341-355.

[69] Tabas, et all., 2012. The Cellular Biology of Macrophages in Atherosclerosis. Cell, 145(3), pp.341355

[70]Tabas, I, 2005. Consequences and Therapeutic Implications of Macrophage Apoptosis in Atherosclerosis The Importance of Lesion Stage and Phagocytic Efficiency. Arterioscler Thromb Vasc Biol, 25, pp.2255-2264.

[71] Tabas, I., 2009. Macrophage Apoptosis in Atherosclerosis: Consequences on Plaque Progression and the Role of Endoplasmic Reticulum Stress. Antioxidants \& Redox Signaling, 11(9), pp.2333 - 2339.

[72] Tabas, I., 2009. Macrophage death and defective inflammation resolution in atherosclerosis. Nature Reviews Immunology, 10(1), pp.36-46. Available at: http://dx.doi.org/10.1038/nri2675.

[73] Taleb, S. et al., 2009. Loss of SOCS3 expression in T cells reveals a regulatory role for interleukin-17 in atherosclerosis. J. Exp. Med, 206(10), pp.2067-2077.

[74] Taleb, S., Tedgui, a \& Mallat, Z., 2008. Regulatory Tcell immunity and its relevance to atherosclerosis. Journal of internal medicine, 263(5), pp.489-99. Available http://www.ncbi.nlm.nih.gov/pubmed/18410592 [Accessed March 20, 2012]

[75] Vanhoutte, P.M., 1997. Endothelial dysfunction and atherosclerosis. Eur Heart J, 18(suppl E), pp.19-29

[76] Wang, S. \& Kaufman, R.J., 2012. The impact of the unfolded protein response on human disease. J. Cell Biol, 197(7), pp.857-867

[77] Wang, W. et al., 2010. Immunomodulatory activity of andrographolide on macrophage activation and specific antibody response. Acta Pharmacologica Sinica, 31, pp.191-201.

[78] Wen-Wan Chao, Yueh-Hsiung Kuo, And .Bi.-Fong Lin, 2010. Anti-inflammatory Activity of New Compounds from Andrographis paniculata by NF-KB Transactivation Inhibition. J. Agric. Food Chem, 58, pp.2505-2512.

[79] Widyawati, T., 2007. Aspek Farmakologi Sambiloto ( Andrographis paniculata Nees ). Majalah Kedokteran Nusantara, 40(3), pp.216-222.
[80] Wongnawa, M. et al., 2012. The effects of Andrographis paniculata ( Burm . f .) Nees on the pharmacokinetics and pharmacodynamics of midazolam in healthy volunteers. Songklanakarin J. Sci. Technol, 34(5), pp.533-539

[81] Xu, Y., 2009. Adaptive immune response-modifying and antimicrobial properties of Andrographis paniculata and andrographolide. The University of Southern Queensland.

[82] zhou Bi-rong, et all. 2011. Fibrinogen and P-selectin expression in atherosclerosis model of Sprague Dawley rat. Chin Med J, p 3768-3772.

[83]Zitvogel, L. et al., 2010. Decoding Cell Death Signals in Inflammation and Immunity. Cell, 140, pp.798-804 